\title{
Dietary Catharanthus roseus modulates intestinal microarchitecture in broilers
}

\author{
S. Yasmin ${ }^{1}$, M.S. Yousaf ${ }^{1 \#}$, K.A. Majeed ${ }^{1}$, M.A. Rashid ${ }^{3}$, S.K. Tahir ${ }^{1}$, M. Numan ${ }^{3}$, R. Mustafa ${ }^{4}$, \\ S.I. Nagra ${ }^{5}$, H. Zaneb ${ }^{6}$ \& H. Rehman ${ }^{1}$ \\ ${ }^{1}$ Department of Physiology, University of Veterinary and Animal Sciences, Lahore, Pakistan \\ ${ }^{2}$ Department of Animal Nutrition, University of Veterinary and Animal Sciences, Lahore, Pakistan \\ ${ }^{3}$ Veterinary Research Institute, Lahore, Pakistan, ${ }^{4}$ Sub-campus Toba Tek Singh, University of Agriculture Faisalabad, \\ Faisalabad, Pakistan, ${ }^{5}$ Department of Zoology, University of Central Punjab, Lahore, Pakistan, ${ }^{6}$ Department of Anatomy \\ and Histology, University of Veterinary and Animal Sciences, Lahore, Pakistan
}

(Received 22 December 2020; Accepted 28 April 2021; Published 16 August 2021)

Copyright resides with the authors in terms of the Creative Commons Attribution 4.0 South African Licence.
See: http://creativecommons.org/licenses/by/4.0/za
Condition of use: The user may copy, distribute, transmit and adapt the work, but must recognise the authors and the South African
Journal of Animal Science.

\begin{abstract}
The study evaluated the efficacy of ethanolic extracts of Catharanthus roseus (C. roseus) in altering growth performance, viscera development and intestinal microarchitecture in broilers. Day-old broiler chicks $(n=175)$ were randomly divided into seven groups $(n=25 /$ group $)$ with 5 replicates $(n=5)$. The chicks in the control groups were fed a corn-soya-based basal diet, whereas groups 2 - 4 had the same basal diets supplemented with $0.05 \%, 0.1 \%$, and $0.2 \%$ ethanolic leaf extracts (ELE), respectively. Chicks in groups $5-7$ were fed the basal diet supplemented with $0.05 \%, 0.1 \%$, and $0.2 \%$ ethanolic root extracts (ERE) of $C$. roseus, respectively. The growth performance and feed conversion ratio remained unchanged, but feed consumption of birds supplemented with $0.1 \%$ ERE increased in weeks 1 and 3 . The relative length of the small intestine was lower in the $0.05 \%$ ERE group compared with the control. Villus height, width, surface area, and lamina propria thickness were higher in the 0.1\% ERE group in all three segments of the small intestine than in the control. Broilers supplemented with $0.1 \%$ ERE performed better in terms of feed consumption and improved intestinal microarchitecture of the small intestine.
\end{abstract}

\footnotetext{
Keywords: feed efficiency, growth performance, intestinal histomorphology, poultry, phytobiotics

\#Corresponding author: drmshahbaz@uvas.edu.pk
}

\section{Introduction}

The efficiency of antibiotics in poultry and livestock production resulted in extensive use of these synthetic substances. However, low doses as growth promoters (AGPs) resulted in increased microbial resistance to antibiotics (Rochfort et al., 2008). Developed countries banned the use of AGPs in poultry and livestock in the early 2000s. However, this resulted in the re-emergence of infections with harmful effects on animal performance. This led to a search for alternatives to antibiotics (Gheisar \& Kim, 2018). Phytogenic feed additives, phytobiotics or herbs may be potential alternatives to AGPs. Phytobiotics are botanically derived products such as herbs, essential oils, and oleoresins that may be mixed in animal feed to enhance production performance because of their antimicrobial, anti-inflammatory, and antioxidant actions (Windisch et al., 2008).

Phytobiotics possess a broad variety of functions in poultry and livestock nutrition, which include feed intake stimulation and antimicrobial, coccidiostatic, anthelmintic and immunostimulating properties (Grashorn, 2010) and have gained interest as an alternative to AGPs in broiler production. However, information about their modes of action and application is still limited (Windisch et al., 2008). Catharanthus roseus (C. roseus) is an ornamental shrub that belongs to the family Apocynaceae. It exhibits pharmaceutical properties such as being anti-diarrheal, antimicrobial, antihyperglycemic (Renjini et al., 2017), antihyperlipidemic, wound healing, and antioxidant (Karuna \& Saralakumari, 2011). Caranthus roseus presents antimicrobial activity against pathogenic microbes such as Escherichia coli, Staphylococcus aureus, Bacillus cereus, Klebsiella pneumoniae, and Pseudomonas aeruginosa owing to indole alkaloids and phenolic compounds (Renjini et al., 2017). 
The antioxidant activity of $C$. roseus (Karuna \& Saralakumari, 2011) is probably the result of phenolic compounds, oxalic acid, and anthocyanins (flavonoids) in the leaves and roots. These prevent lipid peroxidation by scavenging reactive oxygen species. Anthocyanins, colored water-soluble glycosylated pigments belonging to the phenolic group, are effective against the lecithin-liposome system and low-density lipoproteins (Garcia et al., 2007). Based on these properties, it was hypothesized that ethanolic extracts of the leaf and root of $C$. roseus could be an alternative to the AGPs and would enhance the production potential of broilers. The present research was designed to examine the potential use of ethanolic extracts of $C$. roseus leaves and roots as phytobiotic growth promoters on the production performance, viscera development, and microarchitecture of the intestinal tract in broilers.

\section{Materials and Methods}

The Institutional Animal Ethics Committee (Letter No. DR/1944 dated 4-12-2018) of the University of Veterinary and Animal Sciences (UVAS), Lahore, approved the experiment. All methods were performed according to the guidelines of animal experimentation.

Day-old Cobb 500 broiler chickens $(n=175)$ were randomly distributed in seven experimental groups ( $n=25$ /group). Each group was further divided into five replicates $(n=5$ per replicate). Chicks in Group I served as a control and were offered antimicrobials and a coccidiostat-free corn-soya-based basal diet (Table 1), as described by Yousaf et al. (2016).

Table 1 Ingredients and nutritive value of basal diet used in evaluating supplementation of broiler diets with Catharanthus roseus

\begin{tabular}{|c|c|c|}
\hline Ingredients, \% & Starter feed & Grower feed \\
\hline Maize & 56.49 & 59.29 \\
\hline Soybean meal ( $48 \%$ crude protein) & 33.80 & 29.80 \\
\hline Soy oil & 3.70 & 5.00 \\
\hline Sunflower oil & 1.50 & 1.50 \\
\hline Calcium carbonate & 1.48 & 1.48 \\
\hline Monocalcium phosphate & 1.42 & 1.34 \\
\hline Premix $^{1}$ & 1.20 & 1.20 \\
\hline DI-Methionine & 0.26 & 0.26 \\
\hline L-Lysine-HCL & 0.13 & 0.12 \\
\hline L-Threonine & 0.02 & 0.02 \\
\hline I-Tryptophan & & 0.02 \\
\hline \multicolumn{3}{|l|}{ Nutrient composition } \\
\hline Metabolizable energy, MJ/kg & 12.62 & 13.05 \\
\hline Crude protein, g/kg & 22.20 & 20.50 \\
\hline Lysine, $\mathrm{g} / \mathrm{kg}$ & 1.30 & 1.17 \\
\hline Methionine, $\mathrm{g} / \mathrm{kg}$ & 0.59 & 0.57 \\
\hline Methionine+cystine, $\mathrm{g} / \mathrm{kg}$ & 0.96 & 0.90 \\
\hline Threonine, $\mathrm{g} / \mathrm{kg}$ & 0.88 & 0.81 \\
\hline Tryptophan, g/kg & 0.24 & 0.22 \\
\hline Crude fibre, $\mathrm{g} / \mathrm{kg}$ & 2.35 & 2.29 \\
\hline Crude fat, $\mathrm{g} / \mathrm{kg}$ & 9.71 & 9.87 \\
\hline Calcium, g/kg & 0.90 & 0.88 \\
\hline Phosphorus, g/kg & 0.70 & 0.66 \\
\hline Sodium, g/kg & 1.60 & 1.60 \\
\hline
\end{tabular}

\footnotetext{
${ }^{1}$ Vitamin A : $400000 \mathrm{U}$ Vit. A; vitamin B1: $40000 \mathrm{U}$, vitamin B2:; $250 \mathrm{mg}$, vitamin B6: $2500 \mathrm{mg}$, vitamin B12; $2000 \mu \mathrm{g}$, vitamin D3: $25000 \mu \mathrm{g}$, vitamin E ( $\alpha$-Tocopherole acetate): $8000 \mathrm{mg}$, vitamin K3: $300 \mathrm{mg}$, nicotinic acid: $250 \mathrm{mg}$, biotin:
} 
$400 \mathrm{mg}$, calcium pantothenate acid: $1000 \mathrm{mg}$, choline chloride: $100 \mathrm{mg}$, folic acid: $5000 \mathrm{mg}$, zinc: $80000 \mathrm{mg}$, manganese: $2000 \mathrm{mg}$, iron: $1200 \mathrm{mg}$, copper: $6000 \mathrm{mg}$, cobalt: $45 \mathrm{mg}$, calcium: $35 \mathrm{mg}$, selenium: $30 \mathrm{mg}$, magnesium: $130 \mathrm{~g}$, sodium: $55 \mathrm{~g}$ per $\mathrm{kg}$

Catharanthus roseus was collected from the UVAS campus in Lahore. A plant specimen was submitted to the herbarium of the Department of Botany, Government College University, Lahore, for authentication (catalogue number GC-Herb-Bot-3415). Leaves and roots of the plant were separated, washed, and then dried in the shade. The dried plant material was weighed and ground into a fine powder. Ethanolic extracts of leaves and roots of $C$. roseus were prepared separately using Soxhlet extraction as described by Azwanida (2015) with a little modification. Briefly, $50 \mathrm{~g}$ of the dried powder of roots or leaves was taken and loaded in the inner tube of the Soxhlet apparatus, placed in a round-bottomed flask containing $500 \mathrm{ml}$ of ethanol, and heated for 24 hours $\left(40^{\circ} \mathrm{C}\right)$. This extract was then filtered with Whatman filter paper No 1. The filtrate was concentrated with a rotary evaporator (Eyela® rotary vacuum evaporator, USA) and the solvent was removed in a hot air oven at $40{ }^{\circ} \mathrm{C}$ to obtain an alcohol-free residual extract. The yield of residual leaf and root extracts of $C$. roseus was $20 \%$ and $17 \%$, respectively.

The birds in groups 2 - 4 were fed the same basal diet supplemented with ethanolic extracts of the leaf (ELE) of C. roseus at rates of $0.05 \%, 0.1 \%$, and $0.2 \%$, respectively. Similarly, the basal diet was supplemented with ethanolic extracts of root (ERE) of $C$. roseus at the rates of $0.05 \%, 0.1 \%$, and $0.2 \%$, respectively, was fed to groups 5 - 7 .

Chicks were raised on wood-shaved litter as bedding material. Temperature and shed humidity were controlled and chicks were provided 24 hours of lighting throughout the period of 35 days. Chicks were fed ad libitum, and health status was observed daily. All the chicks were immunized against Newcastle disease virus (Ceva-Phylaxia, Budapest, Hungary) on day 4 and day 20, and infectious bursal disease virus (Lohman Animal Health) on day 8 and day 24 intraocularly and in drinking water, respectively. The bodyweight (BW) of each bird was measured on day 1 and then weekly until the end of the experiment. Feed consumption (FC) and mortality (if any) were recorded daily. Feed conversion ratio (FCR) was calculated weekly using BW and FC. On day 35 , ten birds from each group (2 birds/replicate) were randomly selected, weighed, and exsanguinated. Then the abdominal cavity was opened to collect the viscera. The weights of the viscera were recorded and the lengths of the caeca and small intestine were measured to calculate their relative weights and lengths.

To study intestinal morphology, 2-cm fragments from each duodenum, jejunum, and ileum of the small intestine were separated and washed with fresh and chilled normal saline solution $(0.9 \%)$. Tissue samples were fixed in $10 \%$ neutral buffered formalin solution for 48 hours. The paraffin embedding technique was employed. To process tissue 4-5 $\mu \mathrm{m}$ tissue sections were obtained for light microscopy (Labomed ${ }^{\Theta}$ USA) and stained with haematoxylin and eosin for histomorphometric studies (Suvarna \& Layton, 2018). The Prog Res $® 2.1 .1$ Capture Prog Camera Control software was used for imaging the samples. Five villi per slide were taken from the tissue based on intact lamina propria to measure morphometric variables. The studied variables include villus height (VH), width (VW), crypt depth (CD), villus surface area (VSA), ratio of villus height to crypt depth ratio (VH/CD), lamina propria thickness (LPT), muscularis mucosae thickness (MMT), and muscularis externa thickness (MET). Villus height was calculated from the top of each villus to the lamina propria (LP), whereas VW was taken from the centre of each villus. Crypt depth was measured from the depth of the invagination between neighbouring villi. The thickness of lamina propria was measured from the villus base to muscularis mucosae. The MMT and MET were calculated across the villus width. The formula used to calculate the villus surface area (VSA) was as follows:

$$
\mathrm{VSA}=(2 \pi) \times(\mathrm{VW} / 2) \times(\mathrm{VH})
$$

Data were analysed with one-way analysis of variance (SPSS Inc. Chicago, IL, USA version 20.0). The normality of data was checked by the Shapiro-Wilk test. Differences in the means were considered significant at $P<0.05$. Group means were compared by Tukey's post-hoc tests if differences were significant.

\section{Results and Discussion}

Growth performance (Table 2), feed consumption (Table 3), and FCR (Table 4) were similar among all groups throughout the experiment. These results agree with studies in which supplementation of $C$. roseus, phytobiotics and essential oils showed no observable changes in the growth performance of broilers (Yasmin, 2013; Ahsan et al., 2018). Contrary to the current findings, Yasodha et al. (2019) reported that bodyweight gain and FCR were improved by supplementation of diets for broilers with phytogenic feed additives. Leskovec et al. (2018) reported that the presence of polyphenols in phytobiotics might improve 
growth performance in birds, although there was variability in the results. For example, some phytobiotics caused an increase (Bravo et al., 2014), decrease or had no effect (Rezar \& Salobir, 2014) on production performance. Feed consumption of birds supplemented with $0.1 \%$ ERE was higher $(P<0.05)$ compared with the control group in the first and third weeks. However, in the second, fourth, and fifth weeks FC remained the same among groups (Table 3). These results agree with others (Amer et al., 2017; Yasodha et al., 2019), which reported that supplementation of phytobiotics in broilers improved FC. Herbal extracts can stimulate appetite and endogenous secretions such as enzymes in poultry that may improve feed intake (Vidanarachchiet al., 2005). Varying results of the effects of feed additives on performance in broilers have been reported in the literature. Researchers such as Angel et al. (2005) reported that in a clean environment growth promoters were ineffective, whereas the effects of growth promoters were more obvious (Cross et al., 2007) in animals that were housed in unhygienic)environments or were in poor health, Consequently, the environmental conditions in which birds are reared may affect their performance. In addition, the phytochemical composition of phytobiotics might affect the growth performance of birds. The extracts of $C$. roseus contained alkaloids, phenolic compounds and flavonoids with antimicrobial and antioxidant properties that might have played an important role in the improvement of feed intake in broilers (Shoba, 2017; Pham et al., 2019).

Table 2 Effects of supplemental Catharanthus roseus ethanolic extracts on bodyweight ( $\mathrm{g}$ ) of broilers, five replicates with five birds/replicate

\begin{tabular}{|c|c|c|c|c|c|}
\hline Treatment & Week 1 & Week 2 & Week 3 & Week 4 & Week five \\
\hline Control & $110 \pm 3$ & $303 \pm 17$ & $594 \pm 22$ & $1035 \pm 32$ & $1542 \pm 35$ \\
\hline $0.05 \%$ ELE & $112 \pm 1$ & $302 \pm 10$ & $591 \pm 14$ & $1116 \pm 38$ & $1631 \pm 49$ \\
\hline $0.1 \%$ ELE & $111 \pm 2$ & $312 \pm 20$ & $633 \pm 16$ & $1134 \pm 23$ & $1654 \pm 43$ \\
\hline $0.2 \%$ ELE & $108 \pm 2$ & $277 \pm 9$ & $578 \pm 24$ & $1122 \pm 27$ & $1597 \pm 49$ \\
\hline $0.05 \%$ ERE & $112 \pm 3$ & $285 \pm 9$ & $609 \pm 19$ & $1168 \pm 53$ & $1652 \pm 13$ \\
\hline $0.1 \%$ ERE & $115 \pm 1$ & $308 \pm 18$ & $612 \pm 8$ & $1121 \pm 11$ & $1658 \pm 24$ \\
\hline $0.2 \%$ ERE & $110 \pm 3$ & $269 \pm 8$ & $567 \pm 40$ & $1062 \pm 39$ & $1564 \pm 58$ \\
\hline
\end{tabular}

ELE: ethanolic leaf extract; ERE: ethanolic root extract

Table 3 Effects of supplemental Catharanthus roseus ethanolic extracts on feed consumption (g) of broilers, five replicates with five birds/replicate

\begin{tabular}{lllllr}
\hline Treatment & Week 1 & Week 2 & Week 3 & Week 4 & Week 5 \\
\hline Control & $126 \pm 2^{\mathrm{b}}$ & $371 \pm 15$ & $499 \pm 10^{\mathrm{b}}$ & $729 \pm 13$ & $914 \pm 44$ \\
$0.05 \%$ ELE & $132 \pm 1^{\mathrm{ab}}$ & $352 \pm 8$ & $475 \pm 11^{\mathrm{b}}$ & $735 \pm 9$ & $957 \pm 28$ \\
$0.1 \%$ ELE & $133 \pm 1^{\mathrm{ab}}$ & $359 \pm 20$ & $478 \pm 13^{\mathrm{b}}$ & $772 \pm 17$ & $1010 \pm 26$ \\
$0.2 \%$ ELE & $133 \pm 3^{\mathrm{a}}$ & $343 \pm 4$ & $466 \pm 7^{\mathrm{b}}$ & $746 \pm 13$ & $931 \pm 10$ \\
$0.05 \%$ ERE & $136 \pm 1^{\mathrm{a}}$ & $355 \pm 6$ & $504 \pm 9^{\mathrm{b}}$ & $775 \pm 27$ & $961 \pm 30$ \\
$0.1 \%$ ERE & $138 \pm 1^{\mathrm{a}}$ & $391 \pm 8$ & $587 \pm 5^{\mathrm{a}}$ & $753 \pm 14$ & $959 \pm 65$ \\
$0.2 \%$ ERE & $130 \pm 2^{\mathrm{ab}}$ & $360 \pm 8$ & $478 \pm 9^{\mathrm{b}}$ & $739 \pm 24$ & $950 \pm 15$
\end{tabular}

${ }^{a, b}$ Within a column, means with a common superscript did not differ with probability $P=0.05$

ELE: ethanolic leaf extract; ERE: ethanolic root extract 
Table 4 Effects of supplemental Catharanthus roseus ethanolic extracts (leaf and root) on feed conversion ratio of broilers, five replicates with five birds/replicate

\begin{tabular}{lccccc}
\hline Treatment & Week 1 & Week 2 & Week 3 & Week 4 & Week 5 \\
\hline Control & $1.66 \pm 0.10$ & $1.96 \pm 0.17$ & $1.73 \pm 0.11$ & $1.65 \pm 0.03$ & $1.80 \pm 0.06$ \\
$0.05 \%$ ELE & $1.67 \pm 0.02$ & $1.87 \pm 0.06$ & $1.68 \pm 0.13$ & $1.41 \pm 0.08$ & $1.86 \pm 0.09$ \\
$0.1 \%$ ELE & $1.71 \pm 0.05$ & $1.81 \pm 0.12$ & $1.53 \pm 0.17$ & $1.54 \pm 0.01$ & $1.96 \pm 0.12$ \\
$0.2 \%$ ELE & $1.81 \pm 0.06$ & $2.02 \pm 0.07$ & $1.57 \pm 0.11$ & $1.40 \pm 0.11$ & $2.05 \pm 0.26$ \\
$0.05 \%$ ERE & $1.72 \pm 0.07$ & $2.07 \pm 0.09$ & $1.55 \pm 0.04$ & $1.42 \pm 0.13$ & $2.04 \pm 0.21$ \\
$0.1 \%$ ERE & $1.71 \pm 0.04$ & $2.07 \pm 0.19$ & $1.95 \pm 0.12$ & $1.48 \pm 0.06$ & $1.78 \pm 0.12$ \\
$0.2 \%$ ERE & $1.69 \pm 0.03$ & $2.29 \pm 0.18$ & $1.75 \pm 0.35$ & $1.49 \pm 0.05$ & $1.90 \pm 0.06$
\end{tabular}

ELE: ethanolic leaf extract; ERE: ethanolic root extract

The present study showed that the relative length of the small intestine was lower $(P<0.05)$ in the $0.05 \%$ ERE group compared with the control birds. It was reported that essential oils in the diet decreased intestinal weight and length in broilers (Alçiçek et al., 2004), which was similar to our findings. However, the relative organ weights of the liver, gizzard, heart, spleen, proventriculus, bursa, caeca, and small intestine and the relative length of caeca remained unchanged (Table 5). The present results are similar to those of Hernandez et al. (2004), who found that phytobiotics did not affect viscera.

Table 5 Effects of supplemental Catharanthus roseus ethanolic extracts (leaf and root) on the relative weight and length of the viscera of broilers, five replicates with 5 birds/replicate

\begin{tabular}{llllllll}
\hline Weight & Control & $0.05 \%$ ELE & $0.1 \%$ ELE & $0.2 \%$ ELE & $0.05 \%$ ERE & $0.1 \%$ ERE & $0.2 \%$ ERE \\
\hline Liver & $2.35 \pm 0.11$ & $2.22 \pm 0.06$ & $2.19 \pm 0.04$ & $2.17 \pm 0.09$ & $2.29 \pm 0.07$ & $2.35 \pm 0.14$ & $2.51 \pm 0.17$ \\
Gizzard & $1.25 \pm 0.04^{\mathrm{ab}}$ & $1.10 \pm 0.05^{\mathrm{b}}$ & $1.07 \pm 0.04^{\mathrm{b}}$ & $1.15 \pm 0.05^{\mathrm{ab}}$ & $1.21 \pm 0.06^{\mathrm{ab}}$ & $1.20 \pm 0.03^{\mathrm{ab}}$ & $1.37 \pm 0.08^{\mathrm{a}}$ \\
Proventriculus & $0.35 \pm 0.01$ & $0.36 \pm 0.02$ & $0.36 \pm 0.02$ & $0.35 \pm 0.01$ & $0.37 \pm 0.01$ & $0.40 \pm 0.02$ & $0.38 \pm 0.02$ \\
Heart & $0.45 \pm 0.02$ & $0.41 \pm 0.02$ & $0.78 \pm 0.33$ & $0.43 \pm 0.01$ & $0.44 \pm 0.02$ & $0.48 \pm 0.02$ & $0.46 \pm 0.02$ \\
Spleen & $0.10 \pm 0.01$ & $0.11 \pm 0.01$ & $0.11 \pm 0.01$ & $0.11 \pm 0.01$ & $0.10 \pm 0.01$ & $0.11 \pm 0.01$ & $0.11 \pm 0.02$ \\
$\quad$ Pancreas & $0.23 \pm 0.01$ & $0.22 \pm 0.02$ & $0.19 \pm 0.01$ & $0.19 \pm 0.01$ & $0.20 \pm 0.01$ & $0.21 \pm 0.01$ & $0.24 \pm 0.01$ \\
$\quad$ Bursa & $0.13 \pm 0.02$ & $0.15 \pm 0.01$ & $0.15 \pm 0.01$ & $0.15 \pm 0.01$ & $0.11 \pm 0.01$ & $0.14 \pm 0.01$ & $0.15 \pm 0.01$ \\
$\quad$ Small & $2.16 \pm 0.11$ & $2.07 \pm 0.16$ & $2.19 \pm 0.13$ & $2.12 \pm 0.08$ & $2.11 \pm 0.13$ & $2.09 \pm 0.13$ & $2.43 \pm 0.17$ \\
$\quad$ Intestine & & & & & & & \\
Length & & & & & & \\
$\quad$ Small & $4.07 \pm 0.14^{\mathrm{a}}$ & $3.57 \pm 0.13^{\mathrm{ab}}$ & $3.60 \pm 0.14^{\mathrm{ab}}$ & $3.71 \pm 0.08^{\mathrm{ab}}$ & $3.48 \pm 0.11^{\mathrm{b}}$ & $3.53 \pm 0.10^{\mathrm{ab}}$ & $3.63 \pm 0.17^{\mathrm{ab}}$ \\
$\quad$ Intestine & $0.78 \pm 0.03$ & $0.69 \pm 0.03$ & $0.69 \pm 0.03$ & $0.71 \pm 0.02$ & $0.71 \pm 0.03$ & $0.69 \pm 0.03$ & $0.73 \pm 0.03$ \\
Caeca & & & & & & & \\
\hline
\end{tabular}

a,b Within a column, means with a common superscript did not differ with probability $P=0.05$

ELE: ethanolic leaf extract; ERE: ethanolic root extract

Villus height in the duodenum was higher $(P<0.05)$ in the $0.05 \%$ ELE and $0.1 \%$ ERE groups compared with the control. Villus width, VSA, and LPT were higher $(P<0.05)$ in the $0.1 \%$ ERE groups compared with the control and other groups. The CD was lower $(P<0.05)$ in the $0.2 \%$ ERE compared with the control and other groups. The $\mathrm{VH} / \mathrm{CD}$ was higher $(P<0.05)$ in the $0.2 \%$ and $0.05 \%$ ELE groups. The MMT was lower $(P<0.05)$ in the $0.05 \%$ ERE and $0.2 \%$ ELE groups compared with the control birds. However, MET was lower in the $0.2 \%$ ELE group. In the jejunum, the VH and VSA were higher $(P<0.05)$ in the $0.1 \%$ ERE group compared with the control and other groups. The VW was higher $(P<0.05)$ in the $0.2 \%$ ELE and $0.05 \%$ ERE groups compared with the control. The CD was higher $(P<0.05)$ in the $0.1 \%$ ELE group compared with the control animals. The $\mathrm{VH} / \mathrm{CD}$ and LPT were higher $(P<0.05)$ in the $0.05 \%$ ELE group 
compared with the control and other groups. The MMT and MET were lower in the $0.2 \%$ ERE group compared with the control and other groups. The VH, VW, and VSA in the ileum were higher $(P<0.05)$ in the $0.1 \%$ ERE supplemented group compared with the control and other groups. The LPT was higher $(P<0.05)$ in the $0.05 \%$ and $0.1 \%$ ERE groups than the control group. The MMT was higher $(P<0.05)$ in the $0.05 \%$ ELE group, whereas the $\mathrm{VH} / \mathrm{CD}$ and MET remained the same in all groups (Table 6).

Table 6 Effects of supplemental Catharanthus roseus ethanolic extracts (leaf and root) on histomorphology of small intestinal segments of broilers, five replicates with five birds/replicate

\begin{tabular}{|c|c|c|c|c|c|c|c|}
\hline & Control & $0.05 \%$ ELE & $0.1 \%$ ELE & $0.2 \%$ ELE & $0.05 \%$ ERE & $0.1 \%$ ERE & $0.2 \%$ ERE \\
\hline \multicolumn{8}{|l|}{ Duodenum } \\
\hline $\mathrm{VH}, \mu \mathrm{m}$ & $1277 \pm 103^{b c}$ & $2487 \pm 64^{a}$ & $1542 \pm 67^{b}$ & $1235 \pm 32^{b c}$ & $1555 \pm 146^{b}$ & $2212 \pm 92^{a}$ & $1073 \pm 55^{c}$ \\
\hline$V W, \mu m$ & $159 \pm 17^{\mathrm{cd}}$ & $254 \pm 8^{\mathrm{ab}}$ & $193 \pm 16^{\mathrm{bc}}$ & $120 \pm 5^{d}$ & $226 \pm 31^{b}$ & $316 \pm 11^{a}$ & $114 \pm 3^{d}$ \\
\hline $\mathrm{CD}, \mu \mathrm{m}$ & $238 \pm 10^{b c}$ & $344 \pm 16^{\mathrm{a}}$ & $304 \pm 22^{\mathrm{ab}}$ & $168 \pm 7^{\circ}$ & $233 \pm 21^{c d}$ & $328 \pm 12^{\mathrm{a}}$ & $189 \pm 11^{c d}$ \\
\hline $\mathrm{VH} / \mathrm{CD}$ & $5.3 \pm 0.3^{b c}$ & $7.3 \pm 0.3^{a}$ & $5.2 \pm 0.3^{c}$ & $7.4 \pm 0.3^{\mathrm{a}}$ & $6.9 \pm 0.5^{\mathrm{ab}}$ & $6.8 \pm 0.4^{\mathrm{abc}}$ & $5.9 \pm 0.5^{\mathrm{abc}}$ \\
\hline VSA, $\mathrm{mm}^{2}$ & $664 \pm 108^{\mathrm{bcd}}$ & $1988 \pm 91^{a}$ & $955 \pm 115^{b c}$ & $464 \pm 21^{\mathrm{cd}}$ & $1178 \pm 230^{b}$ & $2203 \pm 131^{a}$ & $384 \pm 19^{d}$ \\
\hline LPT, $\mu \mathrm{m}$ & $126 \pm 15^{b c}$ & $187 \pm 8^{\mathrm{ab}}$ & $149 \pm 1^{b c}$ & $91 \pm 4^{c}$ & $181 \pm 28^{\mathrm{ab}}$ & $239 \pm 14^{\mathrm{a}}$ & $93 \pm 3^{c}$ \\
\hline $\mathrm{MMT}, \mu \mathrm{m}$ & $27 \pm 2^{\mathrm{a}}$ & $26 \pm 1^{a}$ & $23 \pm 1^{\mathrm{ab}}$ & $19 \pm 1^{b}$ & $19 \pm 1^{b}$ & $22 \pm 1^{\mathrm{ab}}$ & $22 \pm 2^{\mathrm{ab}}$ \\
\hline $\mathrm{MET}, \mu \mathrm{m}$ & $145 \pm 6^{\mathrm{ab}}$ & $177 \pm 11^{\mathrm{a}}$ & $204 \pm 13^{\mathrm{a}}$ & $108 \pm 7^{b}$ & $145 \pm 20^{\mathrm{ab}}$ & $196 \pm 23^{a}$ & $187 \pm 18^{\mathrm{a}}$ \\
\hline \multicolumn{8}{|l|}{ Jejunum } \\
\hline $\mathrm{VH}, \mu \mathrm{m}$ & $540 \pm 49^{c}$ & $964 \pm 51^{\mathrm{ab}}$ & $922 \pm 78^{\mathrm{ab}}$ & $739 \pm 45^{\mathrm{bc}}$ & $670 \pm 55^{c}$ & $995 \pm 58^{\mathrm{a}}$ & $744 \pm 32^{\mathrm{bc}}$ \\
\hline $\mathrm{VW}, \mu \mathrm{m}$ & $148 \pm 6^{b c}$ & $209 \pm 19^{a}$ & $219 \pm 15^{\mathrm{a}}$ & $175 \pm 12^{\mathrm{ab}}$ & $174 \pm 13^{\mathrm{ab}}$ & $219 \pm 15^{\mathrm{a}}$ & $112 \pm 6^{c}$ \\
\hline $\mathrm{CD}, \mu \mathrm{m}$ & $183 \pm 14^{\mathrm{ab}}$ & $194 \pm 15^{\mathrm{ab}}$ & $236 \pm 23^{\mathrm{ab}}$ & $180 \pm 12^{\mathrm{ab}}$ & $186 \pm 15^{\mathrm{ab}}$ & $215 \pm 12^{\mathrm{ab}}$ & $168 \pm 6^{b}$ \\
\hline $\mathrm{VH} / \mathrm{CD}$ & $3.0 \pm 0.2^{b}$ & $5.2 \pm 0.4^{\mathrm{a}}$ & $4.4 \pm 0.7^{\mathrm{ab}}$ & $4.2 \pm 0.3^{\mathrm{ab}}$ & $3.9 \pm 0.5^{\mathrm{ab}}$ & $4.8 \pm 0.5^{\mathrm{ab}}$ & $4.5 \pm 0.2^{\mathrm{ab}}$ \\
\hline VSA, $\mathrm{mm}^{2}$ & $255 \pm 29^{b}$ & $642 \pm 73^{a}$ & $658 \pm 89^{a}$ & $401 \pm 31^{b}$ & $382 \pm 56^{b}$ & $677 \pm 48^{\mathrm{a}}$ & $262 \pm 19^{b}$ \\
\hline LPT, $\mu \mathrm{m}$ & $123 \pm 7^{\mathrm{ab}}$ & $159 \pm 20^{a}$ & $161 \pm 15^{\mathrm{a}}$ & $117 \pm 10^{\mathrm{ab}}$ & $131 \pm 15^{\mathrm{a}}$ & $155 \pm 14^{\mathrm{a}}$ & $71 \pm 5.14^{b}$ \\
\hline $\mathrm{MMT}, \mu \mathrm{m}$ & $30 \pm 3^{a}$ & $29 \pm 2^{a}$ & $19 \pm 2^{b}$ & $17 \pm 1^{\mathrm{b}}$ & $21 \pm 2^{\mathrm{ab}}$ & $29 \pm 3^{a}$ & $17 \pm 0.3^{b}$ \\
\hline $\mathrm{MET}, \mu \mathrm{m}$ & $159 \pm 24^{\mathrm{ab}}$ & $164 \pm 17^{\mathrm{ab}}$ & $122 \pm 8^{\mathrm{b}}$ & $122 \pm 13^{b}$ & $165 \pm 13^{\mathrm{ab}}$ & $209 \pm 30^{\mathrm{a}}$ & $119 \pm 10^{b}$ \\
\hline \multicolumn{8}{|l|}{ lleum } \\
\hline $\mathrm{VH}, \mu \mathrm{m}$ & $451 \pm 25^{c}$ & $760 \pm 36^{\mathrm{ab}}$ & $630 \pm 40^{\mathrm{bc}}$ & $579 \pm 48^{\mathrm{bc}}$ & $515 \pm 32^{c}$ & $882 \pm 74^{a}$ & $528 \pm 44^{c}$ \\
\hline $\mathrm{VW}, \mu \mathrm{m}$ & $100 \pm 8.9^{d}$ & $209 \pm 10^{\mathrm{a}}$ & $190 \pm 14^{\mathrm{ab}}$ & $133 \pm 3^{\mathrm{cd}}$ & $145 \pm 6^{b c}$ & $207 \pm 9^{a}$ & $157 \pm 16^{\mathrm{bc}}$ \\
\hline $\mathrm{CD}, \mu \mathrm{m}$ & $124 \pm 9^{d}$ & $200 \pm 10^{\mathrm{ab}}$ & $187 \pm 7^{\mathrm{abc}}$ & $147 \pm 10^{\mathrm{bcd}}$ & $135 \pm 22^{c d}$ & $210 \pm 20^{a}$ & $149 \pm 10^{\mathrm{bcd}}$ \\
\hline $\mathrm{VH} / \mathrm{CD}$ & $3.9 \pm 0.5$ & $3.8 \pm 0.2$ & $3.4 \pm 0.2$ & $4.0 \pm 0.4$ & $4.4 \pm 0.5$ & $4.4 \pm 0.4$ & $3.6 \pm 0.2$ \\
\hline VSA, $\mathrm{mm}^{2}$ & $146 \pm 22^{d}$ & $495 \pm 32^{\mathrm{ab}}$ & $371 \pm 31^{b c}$ & $240 \pm 19^{c d}$ & $238 \pm 22^{c d}$ & $575 \pm 57^{\mathrm{a}}$ & $250 \pm 21^{c d}$ \\
\hline LPT, $\mu \mathrm{m}$ & $91 \pm 10^{c}$ & $169 \pm 16^{\mathrm{a}}$ & $134 \pm 10^{\mathrm{ab}}$ & $85 \pm 4^{c}$ & $103 \pm 7^{\mathrm{bc}}$ & $146 \pm 9^{a}$ & $101 \pm 10^{b c}$ \\
\hline $\mathrm{MMT}, \mu \mathrm{m}$ & $32 \pm 3^{\mathrm{bcd}}$ & $61 \pm 4^{\mathrm{a}}$ & $36 \pm 4^{b}$ & $21 \pm 1^{c d}$ & $20 \pm 2^{d}$ & $33 \pm 4^{\mathrm{bc}}$ & $22 \pm 2^{\mathrm{cd}}$ \\
\hline $\mathrm{MET}, \mu \mathrm{m}$ & $193 \pm 23^{b}$ & $312 \pm 25^{\mathrm{a}}$ & $283 \pm 23^{\mathrm{ab}}$ & $174 \pm 16^{b}$ & $195 \pm 21^{\mathrm{ab}}$ & $208 \pm 42^{\mathrm{ab}}$ & $258 \pm 35^{\mathrm{ab}}$ \\
\hline
\end{tabular}

ELE: ethanolic leaf extract, ERE: ethanolic root extract, VH: villus height, VW: villus width, CD: crypt depth, VH/CD: villus height to crypt depth ratio, VSA: villus surface area, LPT: lamina propria thickness, MMT: muscularis mucosae thickness, MET: muscularis externa thickness

a,b,c,d Within a column, means with a common superscript did not differ with probability $P=0.05$

The small intestine goes through histo-morphological changes, which include an increase in the VH and surface area for digestion and absorption (Panda et al., 2006). In the present study, VH, VW, and VSA in all three segments of the small intestine were higher $(P<0.05)$ in the $0.05 \%$ ELE and $0.1 \%$ ERE groups compared with the control group. The increase in VH and VSA indicates an increase in the absorption rate of available nutrients. The current results are in agreement with others (Garcia et al., 2007; Anwar, 2013), who 
observed that supplementation of $C$. roseus extract caused an increase in VH and VSA. Generally, improved gut health is correlated with long villi in small intestinal segments (Baurhoo et al., 2007) that may be ascribed by the intestinal epithelium to act as a natural protective barrier that protects against toxic substances and pathogenic bacteria (Paul et al., 2007). In the small intestine increased VH relative to larger surface area for nutrients absorption has a direct influence on growth performance. It was observed that an increase in villus height in chickens supplemented with herbal plants and plant-derived products, that may cause a reduction in toxic compounds production by decreasing the total pathogenic bacteria in the intestinal wall and damage to intestinal epithelial cells, inhibiting the villus destruction and decreasing lumen reconstruction which could lead to an alteration in intestinal morphology (Garcia et al., 2007).

The duodenum crypt was deeper in the $0.05 \%$ ELE and $0.1 \%$ ERE supplemented groups than in the control and the crypts in the jejunum were deeper in the $0.1 \%$ ELE supplemented group. Our results are in agreement with other studies that reported that supplementation of Catharanthus roseus and other phytobiotics in broilers increased CD in the jejunum (Anwar, 2013; Olukosi \& Dono, 2014; Kiczorowska et al., 2016). Increased CD is an indicator that the production of immature enterocytes also increased, resulting in a higher tissue turnover rate. The longer villi associated with a deeper crypt in response to the use of $C$. roseus as a feed additive in the current study is an indication of healthy gut development.

The ratio of $\mathrm{VH} / \mathrm{CD}$ was higher in the $0.2 \%$ and $0.05 \%$ ELE groups in the duodenum compared with the control birds. In the jejunum VH/CD was higher in the $0.05 \%$ ELE than in the control. The current results agree with those of others who observed that supplementation of $C$. roseus extract, phytobiotics, and essential oils caused an increase in VH/CD compared with the control birds (Anwar, 2013; Kiczorowska et al., 2016). The digestive capacity of the small intestine is indicated by VH/CD (Macpherson \& Harris, 2004). Therefore, enhanced $\mathrm{VH} / \mathrm{CD}$ is generally associated with improved performance through greater nutrient absorption. Lamina propria thickness (LPT) in the duodenum was higher in the $0.1 \%$ ERE group than in the control. In the jejunum, LPT was higher in the $0.05 \%, 0.1 \%$ ELE, and $0.05 \%, 0.1 \%$ ERE supplemented birds than that of the control. In the ileum, LPT was higher in the $0.05 \%$ and $0.1 \%$ ERE supplemented groups compared to the control group. The present results are in agreement with Anwar (2013), who observed that supplementation of $C$. roseus extract caused an increase in the thickness of LP in broilers as LP contains dendritic cells that defend against infections by increasing mucin production, gut motility, and activating the adaptive immune response (Macpherson \& Harris, 2004).

Muscularis mucosae thickness (MMT) was lower in all groups in the duodenum compared with the control group. MMT thickness in the jejunum was lower in the groups supplemented with $0.1 \%$ and $0.2 \%$ ELE than in the control birds. The thickness of muscularis mucosae in the ileum was higher in the group supplemented with $0.05 \%$ ELE compared with the control. Similarly, the thickness of the muscularis externa in the duodenum was higher in the $0.05 \%, 0.1 \% \mathrm{ELE}$, and $0.1 \%, 0.2 \% \mathrm{ERE}$, whereas, MET in the jejunum was lower in the $0.2 \%$ ERE supplemented group compared with the control. The mucosal thickness indicates the absorption rate of nutrients and germ load in the broilers' intestine. With a decrease in the mucosal thickness, the absorption rate of nutrients is increased and the bacterial load is reduced (Miles et al., 2006; Ahsan et al., 2018) which indicates that it might spare nutrients for animal growth.

\section{Conclusion}

Supplementation of $C$. roseus extracts did not affect growth and FCR, but FC of the birds supplemented with $0.1 \%$ ERE improved in weeks 1 and 3 . The relative length of the small intestine was lower in the $0.05 \%$ ERE group compared with the control. Villus height, VW, VSA, and LPT were improved in the duodenum, jejunum, and ileum with $0.1 \%$ ERE supplementation. Thus, broiler chicks supplemented with $0.1 \%$ ERE had improved feed consumption and histomorphometry of the small intestine.

\section{Acknowledgments}

This work was funded by the Higher Education Commission (HEC) of Pakistan.

\section{Author's Contributions}

SY, MSY, and HR participated in the research design. SY collected and prepared $C$. roseus plant extracts. SY, MSY, MAR, HZ, KAM, SKT, MN, SIN, and RM participated in the conduct of the experiment and data collection. SY and MSY performed laboratory tests and statistical analyses. SY, MSY, and HR prepared the manuscript.

\section{Conflict of Interest Declaration}

The authors certify that there is no conflict of interest regarding the material discussed in the manuscript.

\section{References}


Ahsan, U., Kuter, E., Raza, I., Köksal, B.H., Cengiz, Ö., Yıldız, M., Kızanlık, P.K., Kaya, M., Tatı, O. \& Sevim, Ö., 2018. Dietary supplementation of different levels of phytogenic feed additive in broiler diets: the dynamics of growth performance, caecal microbiota, and intestinal morphometry. Braz. J. Poult. Sci. 20(4), 737-746. http://dx.doi.org/10.1590/1806-9061-2017-0698

Alçiçek, A., Bozkurt, M. \& Çabuk, M., 2004. The effect of a mixture of herbal essential oils, an organic acid or a probiotic on broiler performance. S. Afr. J. Anim. Sci. 34, 217-222

Amer, S.A.,Kishawy, A.T.Y. \& El-Eraky, W.A., 2017. Effect of supplementation the broiler diets with some phytobiotics and probiotics on the growth performance, digestibility, immunity and cecal microbial count. 4th International Food Safety Conference. University of Sadat City, Egypt. Pp. 288-300.

Angel, R., Dalloul, R.A. \& Doerr J., 2005. Performance of broiler chickens fed diets supplemented with a direct-fed microbial. Poult. Sci. 84, 1222-1231. https://doi.org/10.1093/ps/84.8.1222

Anwar, S., 2013. Effect of dietary supplementation of Catharanthus roseus on gross and microstructure of selected internal organs of broiler. MPhil thesis. Dept. Anat. Histo. Univ. Vet. Anim. Sci., Lahore, Pakistan.

Azwanida, N.N., 2015. A review on the extraction methods use in medicinal plants, principle, strength and limitation. Med. Aromat. Plants. 4(196), 2167-0412. https://doi.org/10.4172/2167-0412.1000196

Baurhoo, B., Phillip, L. \& Ruiz-Feria, C., 2007. Effects of purified lignin and mannan oligosaccharides on intestinal integrity and microbial populations in the ceca and litter of broiler chickens. Poult. Sci. 86, 1070-1078. https://doi.org/10.1093/ps/86.6.1070

Bravo, D., Pirgozliev, V. \& Rose, S.P., 2014. A mixture of carvacrol, cinnamaldehyde, and capsicum oleoresin improves energy utilization and growth performance of broiler chickens fed maize-based diet. J. Anim. Sci. 92(4), 15311536. https://doi.org/10.2527/jas.2013-6244

Cross, D., McDevitt, R., Hillman, K. \& Acamovic, T., 2007. The effect of herbs and their associated essential oils on performance, dietary digestibility and gut microflora in chickens from 7 to 28 days of age. Br. Poult. Sci. 48, 496506. https://doi.org/10.1080/00071660701463221

Garcia, V., Catala-Gregori, P., Hernandez, F., Megias, M. \& Madrid, J., 2007. Effect of formic acid and plant extracts on growth, nutrient digestibility, intestine mucosa morphology, and meat yield of broilers. J. Appl. Poult. Res. 16, 55562. https://doi.org/10.3382/japr.2006-00116

Gheisar, M.M. \& Kim, I.H., 2018. Phytobiotics in poultry and swine nutrition - a review. Ital. J. Anim. Sci. 17(1), 92-97. https://doi.org/10.1080/1828051X.2017.1350120

Grashorn, M.A., 2010. Use of phytobiotics in broiler nutrition - an alternative to infeed antibiotics. J. Anim. Feed. Sci. 19(3), 338-347. https://doi.org/10.22358/jafs/66297/2010

Hernandez, F., Madrid, J., Garcia, V., Orengo, J. \& Megias, M.D., 2004. Influence of two plant extracts on broilers performance, digestibility, and digestive organ size. Poult. Sci. 83(2), 169-174. https://doi.org/10.1093/ps/83.2.169

Karuna, R. \& Saralakumari, D., 2011. Preventive effect of Catharanthus roseus (Linn.) against high-fructose diet-induced insulin resistance and oxidative stress in male Wistar rats. J. Diabetes Mellit. 1, 63-70. https://doi.org/10.4236/jdm.2011.13010

Kiczorowska, B., Samolińska, W., Al-Yasiry, A.R.M. \& Kowalczyk-Pecka D., 2016. Effect of Boswellia serrata dietary supplementation on growth performance, gastrointestinal microflora, and morphology of broilers. Ann. Anim. Sci. 16(3), 835-849. https://doi.org/10.1515/aoas-2016-0007

Leskovec, J., Levart, A., Žgur, S., Jordan, D., Pirman, T., Salobir, J. \& Rezar, V., 2017. Effects of olive leaf and marigold extracts on the utilization of nutrients and on bone mineralization using two different oil sources in broilers. J. Poult. Sci. 55, 17-27. https://doi.org/10.2141/jpsa.0170059

Macpherson, A.J. \& Harris, N.L., 2004. Interactions between commensal intestinal bacteria and the immune system. Nat. Rev. Immunol. 4, 478-485. https://doi.org/10.1038/nri1373

Miles, R.D., Butcher, G.D., Henry, P.R. \& Littell, R.C., 2006. Effect of antibiotic growth promoters on broiler performance, intestinal growth parameters, and quantitative morphology. Poult. Sci. 85, 476-485. https://doi.org/10.1093/ps/85.3.476

Gheisar, M.M. \& Kim, I.H., 2018. Phytobiotics in poultry and swine nutrition-a review. Ital. J. Anim. Sci. 17(1), 92-99. https://doi.org/10.1080/1828051X.2017.1350120

Olukosi, O.A. \& Dono, N.D., 2014. Modification of digesta pH and intestinal morphology with the use of benzoic acid or phytobiotics and the effects on broiler chicken growth performance and energy and nutrient utilization. J. Anim. Sci. 92, 3945-3953. https://doi.org/10.2527/jas.2013-6368

Panda, K., Rao, S.V.R. \& Raju, M., 2006. Natural growth promoters have potential in poultry feeding systems. Feed Tech. 10, 23-25.

Paul, S.K., Halder, G., Mondal, M.K. \& Samanta, G., 2007. Effect of organic acid salt on the performance and gut health of broiler chicken. J. Poult. Sci. 44, 389-395. https://doi.org/10.2141/jpsa.44.389

Pham, H.N.T., Sakoff, J.A., Van Vuong, Q., Bowyer, M.C. \& Scarlett, C.J., 2019. Phytochemical, antioxidant, antiproliferative and antimicrobial properties of Catharanthus roseus root extract, saponin-enriched and aqueous fractions. Mol. Biol. Rep. 46(3), 3265-3273. https://doi.org/10.1007/s11033-019-04786-8

Renjini, K.R., Gopakumar, G. \& Latha, M.S., 2017. The medicinal properties of phytochemicals in Catharanthus roseus a review. Eur. J. Pharma. Med. Res. 4, 545-551

Rezar, V. \& Salobir, J., 2014. Effects of tannin-rich sweet chestnut (Castanea sativa mill.) wood extract supplementation on nutrient utilisation and excreta dry matter content in broiler chickens. Eur. Poult. Sci. 78(1), 1-10. https://doi.org/10.1399/eps.2014.42 
Rochfort, S., Parker, A.J. \& Dunshea. F. R., 2008. Plant bioactives for ruminant health and productivity. Phytochemistry 69, 299-322. https://doi.org/10.1016/j.phytochem.2007.08.017

Shoba, V., 2017. Ethnobotanical and phytopharmacological activities of Madagascar periwinkle (Catharanthus roseus) a detailed review. Indo. Am. J. Pharm. Res. 04 (12), 4979-4986. https://doi.org/10.5281/zenodo.1342748

Suvarna, S.K. \& Layton, C., 2013. Bancroft's theory and practice of histological techniques. 8th edition. Elsevier. https://www.elsevier.com/books/bancrofts-theory-and-practice-of-histological-techniques/unknown/978-0-70206886-7

Vidanarachchi, J.K., Mikkelsen, L.L., Sims, I., Iji, P.A. \& Choct, M., 2005. Phytobiotics: Alternatives to antibiotic growth promoters in monogastric animal feeds. Rec. Adv. Anim. Nutr. Austr.15, 131-144.

Windisch, W., Schedle, K.,Plitzner, C. \& Kroismayr, A., 2008. Use of phytogenic products as feed additives for swine and poultry. J. Anim. Sci. 86, E140-E148. https://doi.org/10.2527/jas.2007-0459

Yasmin, S., 2013. Effects of dietary supplementation of Sadabahar (Catharanthus roseus) on serum metabolites, hepatic enzymes, oxidant, and antioxidant status in broilers. MPhil thesis, Dept. of Physiol., Univ. Vet. Anim. Sci., Lahore, Pakistan.

Yasodha, T., Jeevitha, S., Yogesh, S. \& Ramanan, M., 2019. Growth performance parameters of broiler chickens as influenced by herbal poultry feed. Int Res J Anim Vet Sci. 1, 26-30.

Yousaf, M.S., Ijaz, A., Ashraf, K., Rashid, M.A., Hafeez, A., Zaneb, H., Dar, E., Naseer, R., Rabbani, I., Zentek, J. \& Rehman, H., 2016. Comparative effects of different dietary concentrations of $\beta$-galacto-oligosaccharides on growth performance, feed conversion efficiency and organs development in broilers. J. Anim. Plant. Sci. 26, 16031608. 